\title{
A METHOD FOR IDENTIFYING AND EVALUATING CORE COMPETENCIES' CONSTITUENT SKILLS FOR VIRTUAL INDUSTRY CLUSTERS
}

\author{
Jairo Eduardo Moraes Siqueira \\ Email: jems@sc.usp.br \\ Carlos Frederico Bremer \\ Email: bremer@sc.usp.br \\ NUMA -Nucleus of Advanced Manufacturing \\ Engineering School of São Carlos - University of São Paulo \\ Av. Dr. Carlos Botelho, 1465 13560-970 \\ São Carlos - SP - Brazil
}

\begin{abstract}
The importance of identifying and evaluating core competencies relies on the fact that when companies enter the business arena wishing to participate in virtual enterprises, brokers will search and select them based on their core competencies. Core competence is a key concept to define the competitiveness of a company. Due to its abstract sense, this paper proposes a method allowing a concise identification and evaluation of core competencies' constituent skills. Once companies have their core competencies evaluated in terms of their constituent skills, they will be able to provide the information about such competencies, allowing virtual enterprise brokers to work more efficiently, the competence match for a business opportunity exploitation.
\end{abstract}

\section{INTRODUCTION - THE CONCEPT OF COMPETENCE AND THE NEED FOR COMPETENCIES IDENTIFICATION AND EVALUATION}

Since the article "Core competence of the Corporation" (Prahalad \& Hamel, 1990) was published, it generated a new trend within the business environment, with the concept of core competencies, based on the company 's resource based view (Prahalad \& Hamel, 1990).

Several authors proposed different definitions for what is called competence, or core competence of a company. In the MOTION project's final report, Teerhag et al. (1996) define core competence as the profitable usage of skills aiming at an objective oriented performing of a task. Österlund (1997) proposed that a core competence is not represented only by knowledge - tacit or explicit - but by a set of elements as skills, experience and values. For Prahalad \& Hamel (1990), "... core competencies are the collective learning in the organization, specially how to 
coordinate diverse production skills and integrate multiple streams of technologies...".

Hamel (1994) defined three levels of abstraction for competencies within a company, which are described below:

- Meta-Core Competencies: they represent the highest abstraction level for a competence. Meta-core competencies represent what makes a company recognized. Examples of Meta-core competencies are engineering excellence for Daimler-Chrysler, innovation for 3M, etc.;

- Core Competencies: at this level, a competence is considered an aggregation of constituent skills. Examples are culture of innovation in 3M, cross-functional engineering in Daimler-Chrysler, etc.;

- Constituent Skills: they are the basic capabilities of a company, which may compose a company's core competence. Examples are: information technologies of Daimler-Benz, manufacturing systems of Toyota, etc.

It is possible to understand the meta- core competence level as the one that encompasses the emotional appeal a company is recognized, situated at a customer's requirements level, closely handling with them. At this level, the knowledge of the used processes or technologies is not relevant, but the result brought by them to the customer's perception of value. The core competencies may be understood as a linkage between the customer's expectations, and the technologies and processes required meeting them. The constituent skills are the building blocks for core competencies.

However the concept of competence looks innovative and promising for competitive environments, the definitions offered in the literature focus on either the output of competencies (that they create value for the customers) or the attributes of competencies (they are difficult to imitate) (Drejer \& Riis, 1999). There is a gap in showing how to evaluate companies' products, technologies and processes, considering them as constituent skills - building blocks - of the companies' competencies.

Considering that there is a certain difficulty in dealing with the concept of competence itself, in a practice sense (Jarvidan, 1998), the approach of identifying and evaluating (core) competencies in terms of its constituent skills seems to be suitable.

\section{THE EXPLOITATION OF COMPETENCIES WITHIN THE FRAMEWORK FOR GLOBAL VIRTUAL BUSINESS}

According to Molina \& Bremer (1997), within the Framework for Global Virtual Business, Virtual Enterprise Brokers (VEB) will be looking for core competencies in a Virtual Industry Cluster (VIC) to (Figure 1):

- Make a product;

- Perform a or a set of business processes to deliver a product;

- Apply or have access to a technology to make a product;

The VIC should respond to these requirements - or tasks - based on its constituent skills, which should be represented as:

- What type of products it can do;

- What business processes it can perform; 
- What technologies it can use.

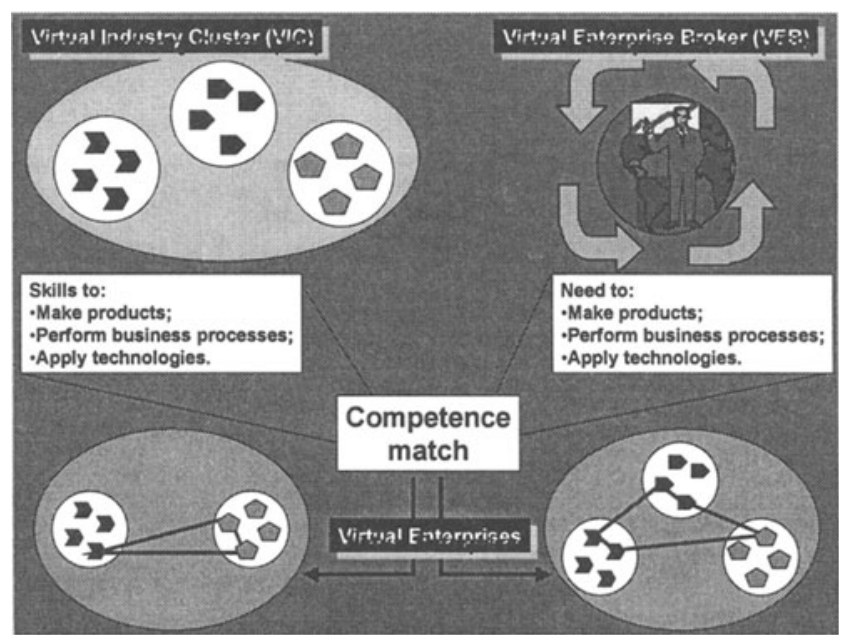

Figure 1 - Competencies on the Framework for Global Virtual Business (Adapted from Molina \& Bremer, 1997)

Following this approach, the required competencies are the required competencies are the capability of matching and fulfilling the tasks provided by the VEB (Molina \& Bremer, 1997). Products, business processes and technologies can be thus understood as core competencies' building blocks, or, constituent skills.

A issue that encourages this approach - by core competencies' constituent skills is that it deals with easily explicitable components, which are well known products, processes and technologies. Moreover, at this level ("building blocks"), they will be integrated in Virtual Enterprises by the VEB.

Before showing the method for identification and evaluation of constituent skills, it is important to define clearly what each one - product, process and technology means:

- Product: it can be understood as a result of a single or more processes. Not necessarily, a product must have physical or material characteristics, it can be a document or a software. In this work, a product will be considered that resulting from manufacturing processes. The representation will be based on project SFB 361 (Eversheim et al., 1996);

- Process: Garvin (1995) classifies processes as management processes, business processes and work processes. In this work, process is always related to business process. Rozenfeld (1996) defines a business process as a phenomena that occurs inside the company. It encompasses a set of activities, which are associated with the information handled by the company, using its resources and organization. A business process constitutes a "coesa" unity and must focus on a type of business, with well defined market/customer and suppliers. Examples of business process are product development, order fulfillment and service (Rozenfeld, 1995); 
- Technology: the ENCICLOPAEDIA BRITANNICA (2000) defines a technology as "the deployment of scientific knowledge for practical issues of human life, or applied for change and manipulation of the human environment". The Merrian-Webster (2000) dictionary defines technology as "the practical deployment of scientific knowledge in a specific area, or a specific way to accomplish a task by using processes, methods or knowledge". Moreover, a classification proposed by Teerhag et al. (1996) will be adopted. These classification sub-divides technologies as:

$\checkmark$ Human skills: these technologies encompass personal skills for technical and managerial tasks, and are related to the competitive and profitable use of specific tools to accomplish those tasks;

$\checkmark$ Organizational practices: they represent the practices and methods adopted by the company's organization on performing its business process;

$\checkmark$ Resources: these are all the physical resources used by the company, like machine tools, computers, LAN's, facilities and so forth.

However, the breakdown shown above does not provide the necessary support to identify and evaluate technologies as constituent skills of core competencies, specifically the human skills and the organizational practices, which may be considered as a part of the company's knowledge.

In accordance with Nonaka \& Takeuchi (1997), the knowledge a company has can be classified as explicit or tacit ones. Explicit knowledge are those that can be formalized as texts, databases, and so forth, while tacit knowledge are considered inherent to a person, acquired through time and experimentation.

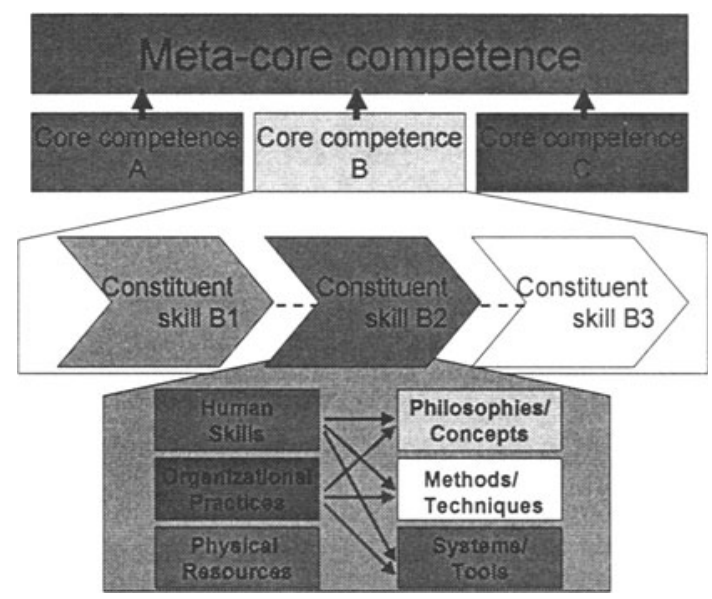

Figure 2 - An overview of the constituent skills representation

Silva \& Rozenfeld (1998) proposed a typology for representing explicit knowledge, where they are considered as being: 
- Philosophies/Concepts: they are used to create theoretical and generic basis, e.g. Activity Based Costing (ABC) or Project Management;

- Techniques/Methods: they are structured in steps or related to something more specific, e.g. Computer Aided Design (CAD) or Quality Function Deployment (QFD);

- Tools/Systems: they are generally related to commercial solutions, e.g. Product Data Management (PDM) or Electronic Document Management (EDM).

Thus, the company's human skills or organizational practices can be classified as explicit knowledge, in a lower level as philosophies/concepts, methods/techniques or tools/systems (Figure 2).

\subsection{Products as a Constituent Skill}

The method consists of two spreadsheets, the Product's Internal Evaluation Spreadsheet (PIES) and the Qualitative Evaluation Spreadsheet (QEPS). The PIES identifies the products and aims to provide general information about them. These information consist of:

- Manufacturing typology 1: MTS, MTO, ATO or ETO product;

- Manufacturing typology 2: discrete or continuous process product;

- Classification: according to SFB 361 (Eversheim et al., 1996), it can be a final product, a module, component or a single piece;

- Participation on company's income: percentage of income the referred product provides the company;

- Market-share;

- Specific market growth;

- Life-cycle phase: introduction, growing, maturity and declining.

The criteria market-share, specific market growth and life cycle phase provide balanced weights, which will be used by the next spreadsheet. These weights are from 1 (the lowest) to 4 (the highest). The second spreadsheet, QEP, provides qualitative marks for internal and customer criteria, which are:

- Capability in gaining new customers;

- Capability in gaining new orders;

- Customer's quality perception;

- Possibility to be recycled/retrofitted;

- Level of technological innovation

These criteria are judged according to marks from 1 (lowest value) to 5 (highest value). After collecting data for all the products available in a company, a score is done by summing the marks for all the criteria, then multiplying this sum by the weights given by PIES. A second sum is done, taking into account all the scored sums, thus a $A B C$ curve is drawn.

Those products that contribute with until $50 \%$ percent of the final sum, these will be considered the company core products. However, it is necessary to have workshops within the company, in order to validate the obtained results.

\subsection{Business processes as a Constituent Skill}

This method is based on the work performed by Teerhag et al. (1996). In order to allow a uniform and equal analysis of different companies' business processes, a 
taxonomy was adopted, and it is that from ENAPS (European Network for Advanced Performance Studies). This taxonomy encompasses the following macroprocesses:

- Product Development;

- Obtaining the Customer Commitment;

- Order Fulfillment;

- Service.

The processes are evaluated taking into account both qualitative and quantitative criteria, in internal and external perspectives (Table 1). Each process and its respective sub-processes or activities qualitative marks, from 1 (the lowest) to 5 (the highest). For each sub-process or activity, a balancing weight must be given, from 1 (the lowest) to 3 (the highest).

The criterion for considering a process as a core process, both perspective values (internal and external) must be over $50 \%$. As the same for products, the results must be validated in workshops within the company (Figure 3).

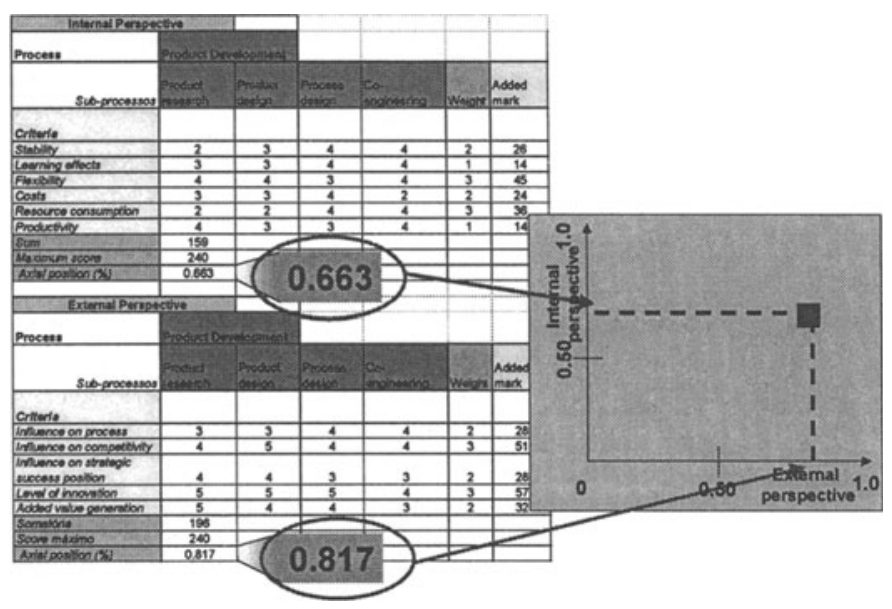

Figure 3 - The evaluation of business processes as constituent skills

\subsection{Technologies as Constituent Skill}

The evaluation of technologies may need of lists with examples that follow the classification explained in the previous sections, for human skills and organizational practices. As so, the company can correctly provide the necessary information.

About the resources as technologies, it is assumed that the most important contribution a company, in terms of physical resources, may provide for VIC's and Virtual Enterprises are its machine tools and other devices, directly linked with production. Then, only manufacturing processes (like grinding, turning or drilling) will be taken into account by this method.

The method consists of evaluating the evolution stage for each technology, within the enterprise and front to the market, and the technology's necessity for competitiveness. Gallon et al. (1995), define each one of these criteria as: 
- Absolute strength: related to how a technology is internally developed;

- Relative strength: related to how, front to main competitors, a technology is developed;

- Criticality: related to how a technology has direct influence on competitiveness.

Each one of these criteria are marked from 1 (the lowest mark) to 5 (the highest mark) (Table 1). After collecting all the data, three different portfolio graphics are plotted (Absolute Strength x Relative Strength, Absolute Strength x Criticality, Relative Strength $x$ Criticality).

Table 1 - Marks for the technologies' evaluation criteria

\begin{tabular}{|c|l|l|l|}
\hline Mark & \multicolumn{1}{|c|}{ Absolute Strength } & Relative Strength & \multicolumn{1}{|c|}{ Criticality } \\
\hline 5 & $\begin{array}{l}\text { Highly refined, with } \\
\text { limited scope for } \\
\text { improvements }\end{array}$ & Total leadership & $\begin{array}{l}\text { Essential for } \\
\text { competitive advantage }\end{array}$ \\
\hline 4 & $\begin{array}{l}\text { Well developed, with } \\
\text { moderated scope for } \\
\text { improvements }\end{array}$ & $\begin{array}{l}\text { Equivalent to the best } \\
\text { practice, without } \\
\text { leadership }\end{array}$ & $\begin{array}{l}\text { Direct and significant } \\
\text { effect on } \\
\text { competitiveness }\end{array}$ \\
\hline 3 & $\begin{array}{l}\text { Partially developed, } \\
\text { with significant scope } \\
\text { for improvements }\end{array}$ & $\begin{array}{l}\text { Within the industry } \\
\text { average }\end{array}$ & $\begin{array}{l}\text { Important for } \\
\text { competitiveness, but } \\
\text { not directly }\end{array}$ \\
\hline 2 & $\begin{array}{l}\text { Initial development } \\
\text { stage }\end{array}$ & $\begin{array}{l}\text { Substantially worse the } \\
\text { industry average }\end{array}$ & $\begin{array}{l}\text { Quite irrelevant for } \\
\text { competitiveness, but } \\
\text { worth for pontual } \\
\text { benefits }\end{array}$ \\
\hline 1 & $\begin{array}{l}\text { Real infancy, with high } \\
\text { scope for development }\end{array}$ & $\begin{array}{l}\text { Sub-developed if } \\
\text { compared with the } \\
\text { industry average }\end{array}$ & $\begin{array}{l}\text { Almost no impact on } \\
\text { competitiveness }\end{array}$ \\
\hline
\end{tabular}

As a criterion for evaluation, a technology will be a core technology if it is present in at least two portfolios, classified with marks higher than the average (value: 3 ). As the same for products and business processes, it needs to be validated within the company.

\section{FINAL REMARKS}

A method for identification and evaluation of core competencies' constituent skills was presented. It validation is partially complete, within the VIRTEC - Virtual Organization of Technology (Bremer et al., 1999) project. The already achieved results have been showing that the method is successful. More then providing information about core competencies' constituent skills, the method is acting as a kind of diagnosis of the companies' skills, helping in re-steering improvement and management efforts. Additionally, it was noticed that a validation of the analyses results within the companies is fundamental.

Because of different approaches of several authors, as shown in section 1, one the most important issues to be treated during the application within the companies of the VIRTEC project was the clear definition of what competencies and skills are.

Finally, the most important conclusion that the method is allowing to be validated, is the one that a company will never contribute with the core competence itself for a VE, but with so many as necessary constituent skills of a certain core 
competence. The core competence that will encompass those skills will be developed within the VE life cycle.

\section{ACKNOWLEDGEMENTS}

The authors would like to thank the nine enterprises of the VIRTEC project, for their commitment and support to the research. The authors would like to thank also FAPESP (Fundação de Amparo a Pesquisa do Estado de São Paulo) for the support on the master research activities ${ }^{1}$.

\section{REFERENCES}

1. Bremer, C. F.; Eversheim, W.; Walz, M.; Molina, A. Global Virtual Business: A Systematic Approach fpr Exploiting Business Opportunities in Dynamic Markets. International Journal of Agile Manufacturing, 1999, 1-2, v.2, n.1, p.1-11.

2. Drejer, A.; Riis, J. O. Competence development and technology: How learning and technology can be meanigfully integrated. Technovation, 1999, n. 19, pp.631-644.

3. Enciclopaedia Britannica. http://www.eb.com, 20.01.2000.

4. Eversheim, W.; Graessler, R.; Kolscheid, A.; SchultenI. Information Management within a Concurrent Engineering Environment, Report 1996, WZL RWTH-Aachen.

5. Gallon, M. R.; Stillman, H. M.; Coates, D. Putting core competency thinking into practice. Research Technology Management, 1995, 5-6, v.38, Is. 3.

6. Garvin, D. A. Leveraging Process for Strategic Advantage. Harvard Business Review, 1995, n.73 (5).

7. Hamel, G.; Heene, A.h Competence Based Competition, 1994, Chichester, John Wiley \& Sons.

8. Jarvidan, M. Core competence: What does it mean in practice?. Long Range Planning, 1998, v. $31, \mathrm{n}$. 1, 60-71.

9. Merrian-Webster Dictionary. Http://www. merrian-webster.com, 20.01.2000.

11. Molina, A. G.; Bremer, C. F. An Information Model to Represent the Core Competencies of Virtual Industry Clusters. Rheinisch-Westfaliche Technische Hochschule - Werkzeugmaschinenlabor, 1997, Final Report.

12. Nonaka, I.; Takeuchi, H. Criação de conhecimento na empresa. Rio de Janeiro, Campus, 1997.

13. Österlund, J. Competence Management by Informatics in R \& D: The Corporate Level. IEEE Transactions on Engineering Management, 1997, v.44, n.2, p.135-145, mai.

14. PICOT, A.; REICHWALD, R.; WIGAND, R. Die Grenzenlose Unternehmung. Weinheim, Gabler Verlag, 1996

15. PORTER, M. Clusters e competitividade. HSM Management, 1999, n.15, p.100-108, Jul-Ago.

16. PRAHALAD, C. K.; HAMEL, G. (The core competence of the corporation. Harvard Business Review, 1999 May/June, pp.79-91.

17. REISS, M.; BECK, T. Kernkompetenzen in virtuellen Unternehmen - Der ideale Strategie-StrukturFit fur wettbwerbsfahige Wertschopfungssysteme. Universităt Stuttgart, 1995.

18. ROZENFELD, H. Reflexðes sobre a manufatura integrada por computador. Escola de Engenharia de São Carlos - Universidade de São Paulo, mimeo, 1995.

19. ROZENFELD, H.; SILVA, S. L. Estruturação dos conhecimentos envolvidos no desenvolvimento do produto com base em um cenário de engenharia simultânea. Proceedings do I Brazilian Congress on Product Development Management, 1998, UFMG - Belo Horizonte - MG, p. 104-113.

20. TEERHAG, O.; DRESSE, S.; KÖLSCHEID, W.; NIEDER, A. Model for Transforming, Identifying and Optimizing Core Processes (MOTION). Rheinisch-Westfaliche Technische Hochschule Werkzeugmaschinenlabor, Final Report, 1996.

The MSc. research title is "Proposal of a Reference Model for the Formation and Management of Virtual Industry Clusters", conducted by Eng.' Jairo Eduardo Moraes Siqueira. 